ORIGINAL ARTICLE

\title{
The predictive value of total serum IgE for a positive allergen specific lgE result
}

\author{
D Sinclair, S A Peters
}

J Clin Pathol 2004;57:956-959. doi: 10.1136/icp.2004.017681

See end of article for authors' affiliations

.....................

Correspondence to: Dr D Sinclair, Department of Clinical Biochemistry, Queen Alexandra

Hospital, Portsmouth PO6 3LY, UK; david.sinclair@ porthosp.nhs.uk

Accepted for publication 6 May 2004
Background: Measurement of total serum lgE and allergen specific lgE is often requested to assess possible allergy. As public awareness increases, so do requests for allergy assessment; unless there is a clear "allergen suspect" in the history, several allergen specific lgE requests may be made. This increases the likelihood of detecting borderline increases in allergen specific $\lg E$ of uncertain relevance, and has important cost implications for the service.

Aims: To provide an evidence base for this observation.

Methods: In this retrospective observational study, results from 301 patients under 16 years of age from whom blood was taken for "allergy testing" from March 2001 to February 2003 were studied.

Results: Allergen specific lgE testing in children with low total serum lgE concentrations (<10 IU/litre) yielded very few positive results (three of 73 children), except in those being investigated for an acute reaction to a single food; when lgE was 11-20 kU/litre, 13 of 73 children had positive allergen specific $\operatorname{lgE}$; in the 21-40 kU/litre lgE group, 16 of 74 children had positive allergen specific lgE and in the 41$80 \mathrm{kU} /$ litre group, 22 of 81 had positive allergen specific lgE.

Conclusions: Allergen specific lgE testing in children with low lgE concentrations ( $<10 \mathrm{kU} /$ litre) produces few positive results in patients with non-specific symptoms. Laboratories should perform allergy testing for specific allergens regardless of total lgE concentration only when there are convincing clinical reasons to do so, and should not proceed with this if the total $\lg E$ is $<10 \mathrm{kU} /$ litre and the presenting symptoms are non-specific.
T he assessment and management of allergic disease in children is a growing and challenging field. Allergic manifestations range from low grade atopic symptoms (eczema, asthma, and rhinitis) and malabsorption symptoms ("faltering growth" and diarrhoea) to acute life threatening anaphylaxis. Where there is a clear history of an acute reaction to a single food, the role of allergy assessment is to confirm the suspected agent and advise appropriate avoidance and rescue measures. Where symptoms are less acute, the role of food allergy may be less clear.

\section{"As public awareness of allergy increases, so does patient/parent pressure for allergy testing"}

The measurement of total serum IgE concentrations and allergen specific IgE is often requested in the assessment of possible allergy. An alternative method of detecting the presence of allergen specific IgE is skin prick testing, which is performed in the clinic setting by a trained nurse or physician, and will not be discussed further in our study of "stand alone" serum IgE concentration and allergen specific IgE measurement. The relative sensitivity and specificity of skin prick testing and serum assays in the detection of allergen specific IgE is unclear-for example, it is widely recognised that individuals with detectable allergen specific IgE may not be clinically intolerant of the allergen.

As public awareness of allergy increases, so does patient/ parent pressure for "allergy testing", often leading to blood being sent for serum IgE concentration and allergen specific IgE testing even in the absence of a clear "allergen suspect" in the history. This increases the likelihood of the detection of borderline increases in allergen specific IgE, of uncertain relevance, and has significant cost implications for the service. Our study describes the relation between increasing concentrations of total serum IgE in children and the detection of allergen specific IgE in the same patients on the same sample.

\section{MATERIALS AND METHODS}

This is a retrospective observational study of results from 301 patients under the age of 16 years from whom blood was taken for allergy testing during a two year period from March 2001 to February 2003, and whose total IgE ranged from 0 to $80 \mathrm{kU} /$ litre (that is, up to and including the UK protein reference laboratory's normal maximum for adults). The requests were initiated either in primary care or by paediatric or dermatology departments, as part of normal clinical practice.

Each child had a total IgE estimation performed (Immulite 2000; DPC Diagnostics, Llanberis, Gwynedd, UK), along with the allergen specific IgE (Unicap 100; Pharmacia, Milton Keynes, UK). Tests were requested by the clinician, and up to a maximum of four tests were carried out each time in accordance with local practice. Age specific reference ranges for total IgE were (kU/litre): newborn $<5 ; 3$ months, $<11$; 1 year, $<29 ; 5$ years, $<52 ; 10$ years, $<63$; and adult, $<81$ ). We classified allergen specific IgE scores as follows; negative, 0 ; low grade, grades 1-2; intermediate grade, grades 3-4; and high grade, grades $5-6$.

Results were grouped first according to increasing total serum IgE concentration: serum IgE concentration $<10 \mathrm{kU} /$ litre, 11-20 kU/litre, 21-40 kU/litre, and 41-80 kU/litre; and second, according to the patient's age in years.

Because this was a retrospective study of laboratory results, with clinical information gained only from the laboratory request form and no impact on clinical management of patients whose results were studied, ethical committee approval and patient consent were not sought. 


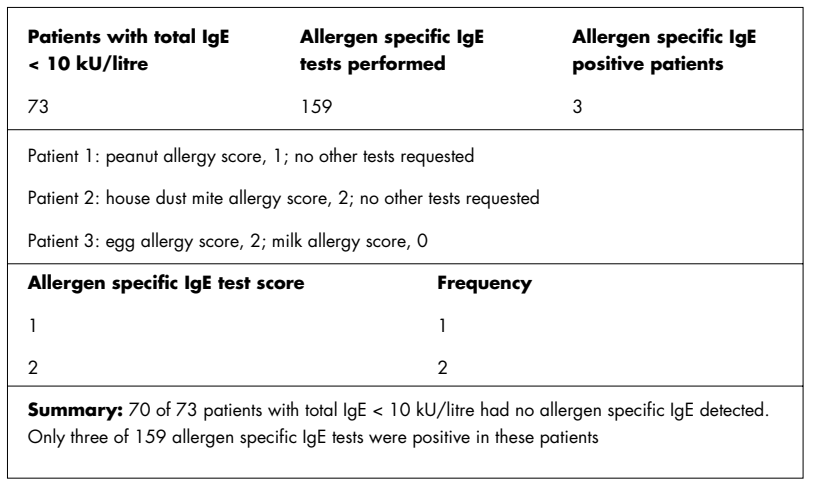

Figure 1 Allergen specific lgE in children with total serum $\lg \mathrm{E}<10 \mathrm{kU} /$ litre.

\section{RESULTS}

Three of 73 children with a total IgE concentration of $<10 \mathrm{kU} /$ litre had a positive allergen specific IgE result for at least one of the 159 allergen specific IgE tests that were requested (fig 1), and these positive results were low grade. Of these cases, two were consistent with a clear clinical history of reaction to a single food (?peanut allergy, ?egg allergy), and both children improved after the introduction of peanut and egg free diets, respectively. The third was a low grade score to house dust mite, which may not have been relevant, in a child with non-specific symptoms (given as "recurrent infections and poor growth"). Seventy of the 73 patients with total $\operatorname{IgE}<10 \mathrm{kU} /$ litre had no allergen specific IgE detected.

Where the total IgE was between 11 and $20 \mathrm{kU} /$ litre (fig 2), more positive allergen specific IgE results were found ( 14 of 150 ), but most of these remained low grade (scores 1-2) and

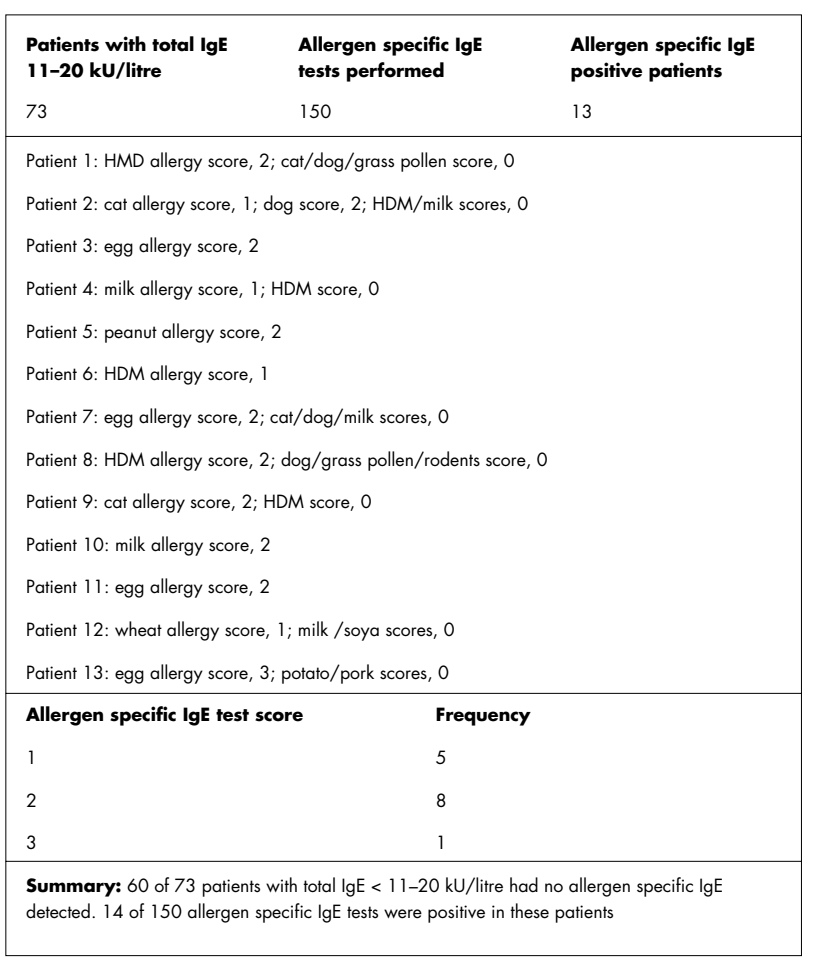

Figure 2 Allergen specific lgE in children with total serum IgE 11$20 \mathrm{kU} /$ litre. HDM, house dust mite.

\begin{tabular}{|c|c|c|}
\hline $\begin{array}{l}\text { Patients with total lgE } \\
21-40 \mathrm{kU} / \text { litre } \\
74\end{array}$ & $\begin{array}{l}\text { Allergen specific IgE } \\
\text { tests performed }\end{array}$ & $\begin{array}{l}\text { Allergen specific IgE } \\
\text { positive patients } \\
16\end{array}$ \\
\hline \multicolumn{3}{|c|}{ Patient 1: milk allergy score, 2; egg/HDM scores, 0} \\
\hline \multicolumn{3}{|c|}{ Patient 2: grass pollen allergy score, 1 ; HDM score, 2; aspergillus scores, 0} \\
\hline \multicolumn{3}{|c|}{ Patient 3: HDM allergy score, 2; aspergillus/cat scores, 0} \\
\hline \multicolumn{3}{|l|}{ Patient 4: peanut allergy score, 3} \\
\hline \multicolumn{3}{|l|}{ Patient 5: milk allergy score, 2} \\
\hline \multicolumn{3}{|c|}{ Patient 6: cat allergy score, 1 ; grass pollen/HDM/peanut scores, 0} \\
\hline \multicolumn{3}{|c|}{ Patient 7: HDM allergy score, 1 ; aspergillus /cladosporium scores, 0} \\
\hline \multicolumn{3}{|c|}{ Patient 8: peanut allergy score, 1 ; penicillin $V$ and $G$ scores, 0} \\
\hline \multicolumn{3}{|c|}{ Patient 9: milk allergy score, 2; egg allergy score, 0} \\
\hline \multicolumn{3}{|l|}{ Patient 10: peanut allergy score, 3} \\
\hline \multicolumn{3}{|c|}{ Patient 11: peanut allergy score, $3 ; \mathrm{HDM} /$ wheat scores, 0} \\
\hline \multicolumn{3}{|c|}{ Patient 12: dog allergy score, 2 ; cat/milk scores, 0} \\
\hline \multicolumn{3}{|c|}{ Patient 13: egg allergy score, 3 ; milk/soya scores, 0} \\
\hline \multicolumn{3}{|c|}{ Patient 14: grass pollen allergy score, 3; cat/HDM scores, 0} \\
\hline \multicolumn{3}{|l|}{ Patient 15: egg allergy score, 2} \\
\hline \multicolumn{3}{|c|}{ Patient 16: HDM allergy score, 4; peanut allergy score, 2; brazil nut score, 0} \\
\hline Allergen specific IgE test score & & Frequency \\
\hline 1 & 4 & \\
\hline 2 & 8 & \\
\hline 3 & 5 & \\
\hline 4 & 1 & \\
\hline $\begin{array}{l}\text { Summary: } 58 \text { of } 74 \text { patients with } \\
\text { detected. } 18 \text { of } 176 \text { allergen specifi }\end{array}$ & $\begin{array}{l}\text { total } \lg E<21-40 \mathrm{kU} / \mathrm{litr} \\
\text { fic } \lg \mathrm{E} \text { tests were positive }\end{array}$ & $\begin{array}{l}\text { allergen specific lgE } \\
\text { patients }\end{array}$ \\
\hline
\end{tabular}

Figure 3 Allergen specific lgE in children with total serum lgE 21$40 \mathrm{kU} /$ litre. HDM, house dust mite.

of uncertain relevance to the clinical indication stated. Sixty of 73 patients with total IgE $11-20 \mathrm{kU} /$ litre had no allergen specific IgE detected. The difference between this group and the total $\mathrm{IgE}<10 \mathrm{kU} /$ litre group is significant (Fisher's exact test; two sided $\mathrm{p}$ value $=0.0149$ )

This trend continued with increasing total IgE (fig 3). Where the total IgE was $21-40 \mathrm{kU} /$ litre, the number of positive allergen specific IgE results increased to 18 of 74 . Most positives were still low grade but there was an increasing number of grade $3-5$ results in this group. Fifty eight of the 74 patients had no allergen specific IgE detected. However, any small differences in the incidence of allergen specific IgE results between the last three groups are irrelevant to this study.

Figure 4 shows the results from those children with total IgE concentrations of $4 \mathrm{l}-80 \mathrm{kU} / \mathrm{litre}$. Fifty nine of the 81 children in this group had no allergen specific IgE detected. The number of positive allergen specific IgE results increased to 18 of 76 .

Table 1 shows the distribution of positive allergen specific IgE results according to age. Although almost all year groups were represented, as might be expected, most of our requests were from children less than 2 years old ( 31 of 54 patients). The correlation coefficient between age of all the children and their total IgE concentrations was 0.1699, indicating that the relation between low IgE and the reduced likelihood of finding positive allergen specific IgE applies across the whole paediatric age range; that is, it is not a phenomenon seen only because the low IgE concentrations were in a very young population. 


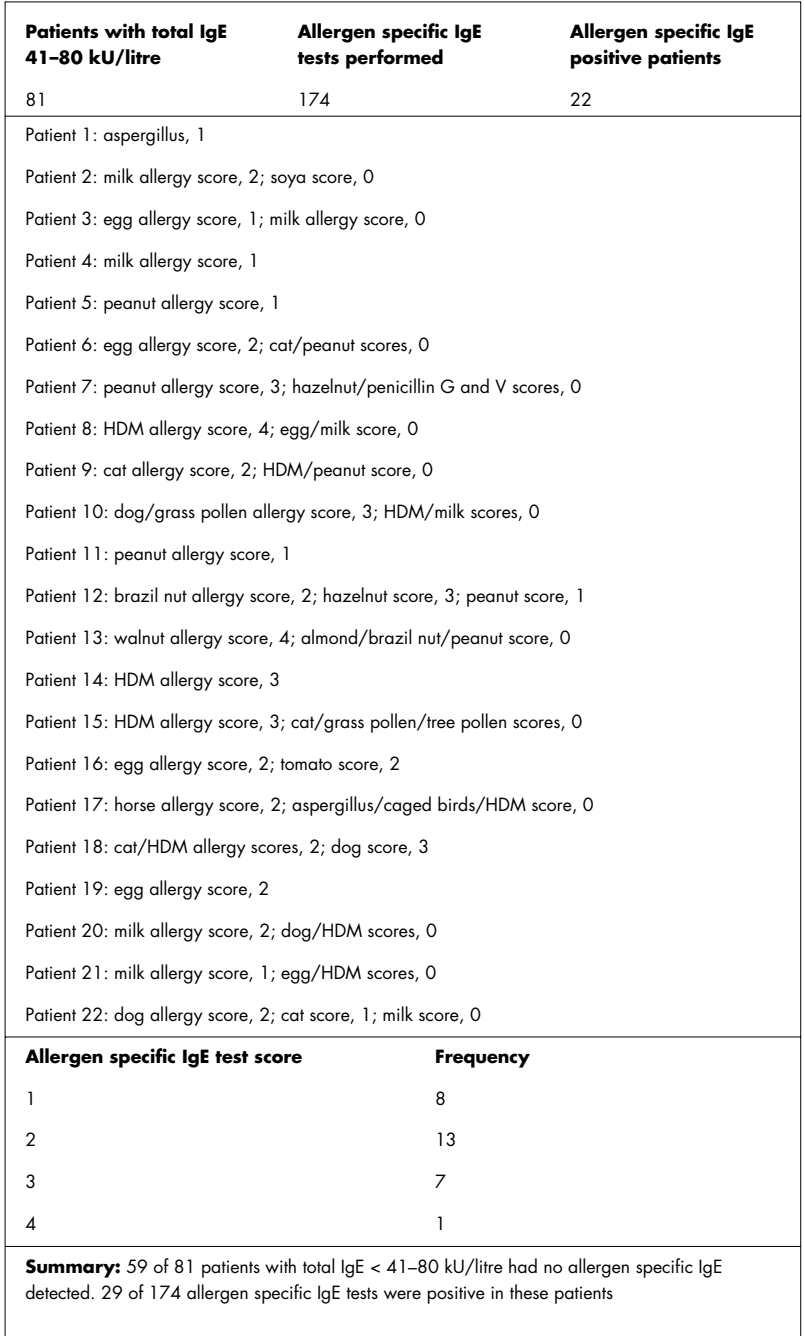

Figure 4 Allergen specific lgE in children with total serum lgE 41$80 \mathrm{kU} /$ litre. HDM, house dust mite.

\section{DISCUSSION}

This retrospective study of request forms and results arose from the observation that children with a very low total IgE rarely, if ever, had allergen specific IgE present. We found that allergen specific IgE testing in children with low IgE concentrations $(<10 \mathrm{kU} /$ litre $)$ produces very few positive results in patients with non-specific symptoms. Other clinics may have stopped using these tests because of indications that they have low relevance to allergic diseases, but our study provides an evidence base for this policy. In our study, as the total IgE increases, there is an increase in the number of patients with allergen specific IgE and also an increasing number of higher grades of allergen specific IgE (table 2).
Table 1 Positive allergen specific lgE grades versus age of patient

\begin{tabular}{|c|c|c|}
\hline Age (years) & No of patients & Allergen specific lgE grades \\
\hline$<1$ & 8 & $\begin{array}{l}\text { Milk2 ( } \times 3) \text {, egg2 }(\times 2) \text {, egg3 }(\times 2) \text {, } \\
\text { wheat } 1\end{array}$ \\
\hline 1 & 19 & $\begin{array}{l}\text { Milk1, milk2 }(\times 2) \text {, egg } 1(\times 2) \text {, egg } 2 \\
(\times 4) \text {, egg } 2 / \text { tom } 2 \text {, cat2, dog } 2, \mathrm{HDM} 1 \text {, } \\
\text { HDM2, PNT1, PNT2 }(\times 2), \text { PNT3 }(\times 2)\end{array}$ \\
\hline 2 & 4 & $\begin{array}{l}\text { Milk2, cat1/dog2, HDM4/PNT2, } \\
\text { Brz2/Haz3/PNT1 }\end{array}$ \\
\hline 3 & 4 & Cat1, HDM3, PNT1, PNT3 \\
\hline 4 & 3 & Cat2/dog3, PNT1, Wlnt4 \\
\hline 5 & 2 & HDM1, ASPE1 \\
\hline 6 & 3 & Milk1, dog3/GPL3, PNT1 \\
\hline 7 & 2 & HDM1, HDM4 \\
\hline 8 & 1 & ASPE2 \\
\hline 9 & 1 & Milk1 \\
\hline 10 & 1 & Cat2 \\
\hline 11 & 2 & GPL1/HDM3, GPL3 \\
\hline 12 & 0 & \\
\hline 13 & 2 & PNT3, HOR2 \\
\hline 14 & 2 & HDM3 $(\times 2)$ \\
\hline
\end{tabular}

Results are given as allergen followed by positive "allergen specific $\lg \mathrm{E}^{\text {" }}$ grade.

ASPE, Aspergillus fumigatus; Brz, brazil nut; GPL, grass pollen; HDM, house dust mite; Haz, hazelnut; HOR, horse; PNT, peanut; Tom, tomato; Wlnt, walnut.

Applying these data to future practice could make a considerable fiscal saving without compromising clinical care in those patients for whom the allergic history is unclear.

Suggested methods of predicting atopic status have ranged from total IgE values in cord blood ${ }^{1}$ and throughout childhood $^{2}$ to neonatal peripheral blood basophil counts. ${ }^{3}$ Most of these have concentrated on looking at positive predictive values for atopy, and it has long been appreciated that a raised $\operatorname{IgE}$ in childhood is a poor predictor (positive predictive value, $50 \%$ ) of allergic disease. ${ }^{45}$ Even where allergen specific IgE is raised, this is not always reflected in clinical diseasein some children followed between 8 and 12 years of age, transient allergen specific IgE antibodies developed. ${ }^{2}$ However, data investigating the ability of low IgE values to predict either positive or negative "allergen specific IgE results" does not appear to have received the same attention.

"Clinical governance demands that all clinicians and staff involved in laboratory medicine take responsibility to look critically at their practices to ensure that expensive tests are used most effectively"

In general, total $\operatorname{IgE}$ concentrations are a relatively crude method of detecting allergic disorders. Normal values will not exclude the presence of "allergic disease", particularly to a single allergen, and raised concentrations can be found in many patients who have no evidence of allergy. ${ }^{6}$

Clinical governance demands that all clinicians and staff involved in laboratory medicine take responsibility to look

Table 2 Summary table

\begin{tabular}{|c|c|c|c|c|c|c|c|}
\hline \multirow{2}{*}{$\begin{array}{l}\text { Total lgE } \\
\text { (kU/l) }\end{array}$} & \multirow[b]{2}{*}{ No of patients } & \multirow{2}{*}{$\begin{array}{l}\text { Allergen specific } \lg E \\
\text { tests performed }\end{array}$} & \multirow{2}{*}{$\begin{array}{l}\text { Patients with positive allergen } \\
\text { specific } \lg E\end{array}$} & \multicolumn{4}{|c|}{ Frequency of positive allergen specific lgE results } \\
\hline & & & & Grade 1 & Grade 2 & Grade 3 & Grade 4 \\
\hline$<10$ & 73 & 159 & 3 & 1 & 2 & 0 & 0 \\
\hline $11-20$ & 73 & 150 & 13 & 5 & 8 & 1 & 0 \\
\hline $21-40$ & 74 & 176 & 16 & 4 & 8 & 5 & 1 \\
\hline $41-80$ & 81 & 174 & 22 & 7 & 13 & 7 & 1 \\
\hline
\end{tabular}




\section{Take home messages}

- Allergen specific lgE testing in children with low $\lg E$ concentrations (<10 kU/litre) produces few positive results in patients with non-specific symptoms

- This study provides an evidence base for the policy of not performing allergen specific lgE testing if the total $\lg E$ is $<10 \mathrm{kU} /$ litre and the presenting symptoms are non-specific

- Nonetheless, laboratories should perform allergy testing for specific allergens, regardless of total $\lg \mathrm{E}$ concentration, when there are convincing clinical reasons to do so

critically at their practices to ensure that expensive tests are used most effectively. In children in whom allergy might be suspected, but no definite clues exist to explain vague symptoms, it is often tempting to request a battery of allergen specific IgE tests in the hope that something comes up as positive. Allergen specific IgE testing is much more expensive-albeit more readily available-than skin prick testing, and one of the criticisms of current practice is the "over use" of blood testing screens for specific allergens, perhaps to the detriment of a careful history and physical examination of the patient.

A study based on the clinical data supplied on request forms does have drawbacks compared with prospective studies, but our experience is that if allergic symptoms are specific these are included in the clinician's justification for the test. Therefore, we feel that although we did not have access to the full clinical history in each case, useful conclusions can still be drawn from these data.

We are not suggesting that total IgE should be used as a screen for subsequent testing in all cases, because if the clinical history is that of a convincing allergic reaction to a single allergen, then a low total IgE does not preclude the presence of allergen specific IgE. With a history of an acute reaction, we would proceed with clinically appropriate allergen specific IgE tests, regardless of total IgE concentration-an approach that was suggested more than 20 years ago. ${ }^{5}$

\section{Authors' affiliations}

D Sinclair, Department of Clinical Biochemistry, Queen Alexandra Hospital, Portsmouth PO6 3LY, UK

S A Peters, St Mary's Hospital, Portsmouth PO6 3AD, UK

\section{REFERENCES}

1 Edenharter G, Bergmann RL, Bergmann KE, et al. Cord blood-lgE as risk factor and predictor for atopic diseases. Clin Exp Allergy 1998;28:671-8.

2 Kjellman NI. Atopic allergy and serum lgE concentrations in randomly selected children followed up from 8 to 12 years of age. Allergy 1984;39:443-50.

3 Calbi M, Giacchetti L, Coppola A, et al. Basophil count of the newborn is not useful in prediction of allergic diseases. Pediatr Med Chir 1996; 18:169-72.

4 Backer V, Ulrik CS, Wendelboe D, et al. Distribution of serum IgE in children and adolescents aged 7 to 16 years in Copenhagen, in relation to factors of importance. Allergy 1992;47:484-9.

5 Bruynzeel PL, Houben LA. Evaluation of total and specific lgE determinations in normal children and children suffering from asthmatic bronchitis with suspected allergic disease. Clin Chim Acta 1981;112:315-23.

6 Saarinen UM, Juntunen K, Kajosaari M, et al. Serum immunoglobulin E in atopic and non-atopic children aged 6 months to 5 years. A follow-up study. Acta Paediatr Scand 1982;71:489-94. 